Prepared in cooperation with the Hopi Tribe

\title{
Aquifer Test at Well SMW-1 near Moenkopi, Arizona
}

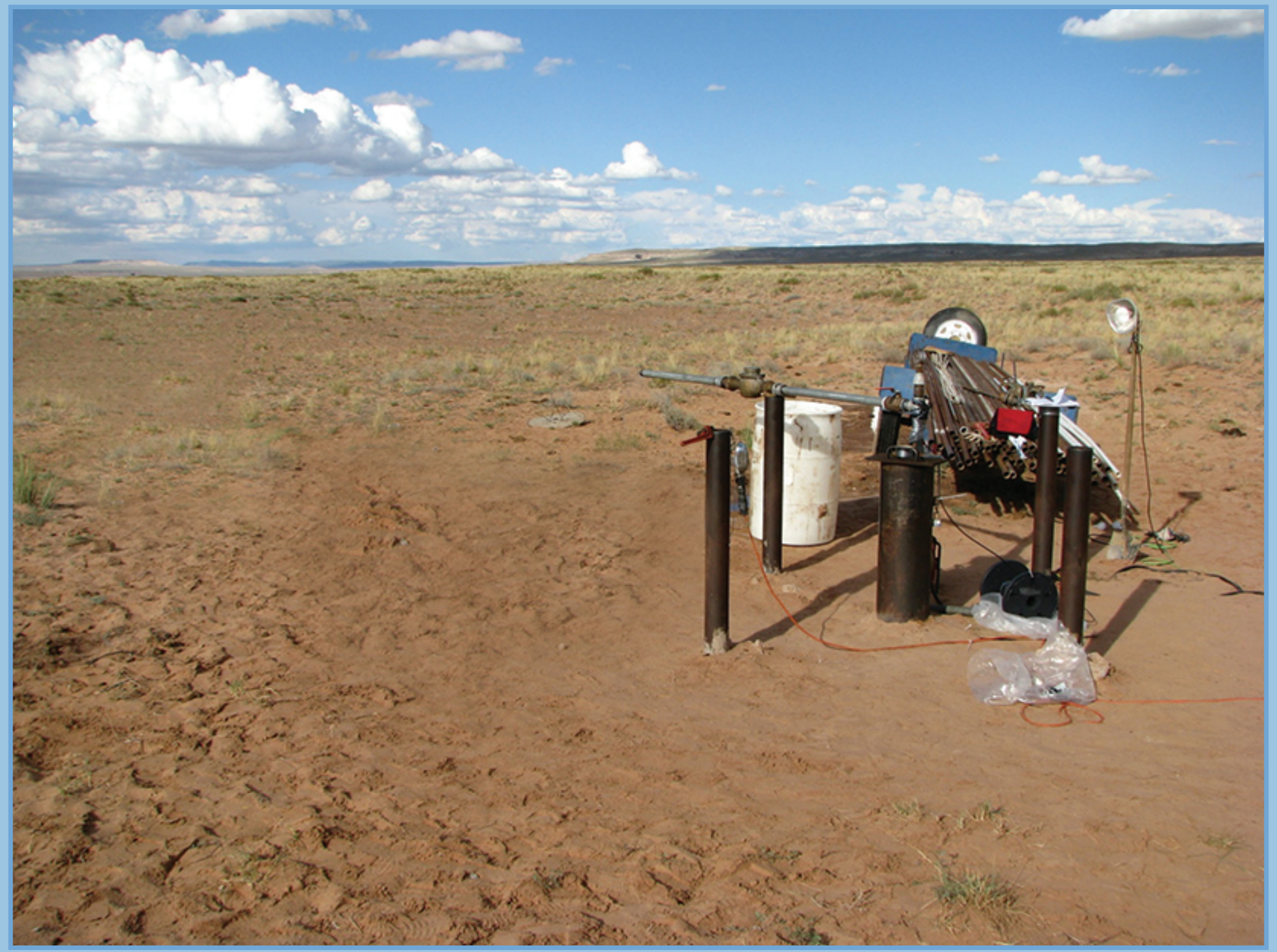

Scientific Investigations Report 2012-5201 
Photograph of Well SMW-1 near Moenkopi, Arizona. 


\section{Aquifer Test at Well SMW-1 near Moenkopi, Arizona}

By Robert L. Carruth and Donald J. Bills

Prepared in cooperation with the Hopi Tribe

Scientific Investigations Report 2012-5201 


\title{
U.S. Department of the Interior \\ KEN SALAZAR, Secretary \\ U.S. Geological Survey \\ Marcia K. McNutt, Director
}

\author{
U.S. Geological Survey, Reston, Virginia: 2012
}

For more information on the USGS - the Federal source for science about the Earth, its natural and living resources, natural hazards, and the environment, visit http://www.usgs.gov or call 1-888-ASK-USGS.

For an overview of USGS information products, including maps, imagery, and publications, visit http://www.usgs.gov/pubprod

To order this and other USGS information products, visit http://store.usgs.gov

Any use of trade, product, or firm names is for descriptive purposes only and does not imply endorsement by the U.S. Government.

Although this report is in the public domain, permission must be secured from the individual copyright owners to reproduce any copyrighted materials contained within this report.

Suggested citation:

Carruth, R.L., and Bills, D.J., 2012, Aquifer Test at Well SMW-1 near Moenkopi, Arizona:

U.S. Geological Survey Scientific Investigations Report 2012-5201, 11 p. 


\section{Contents}

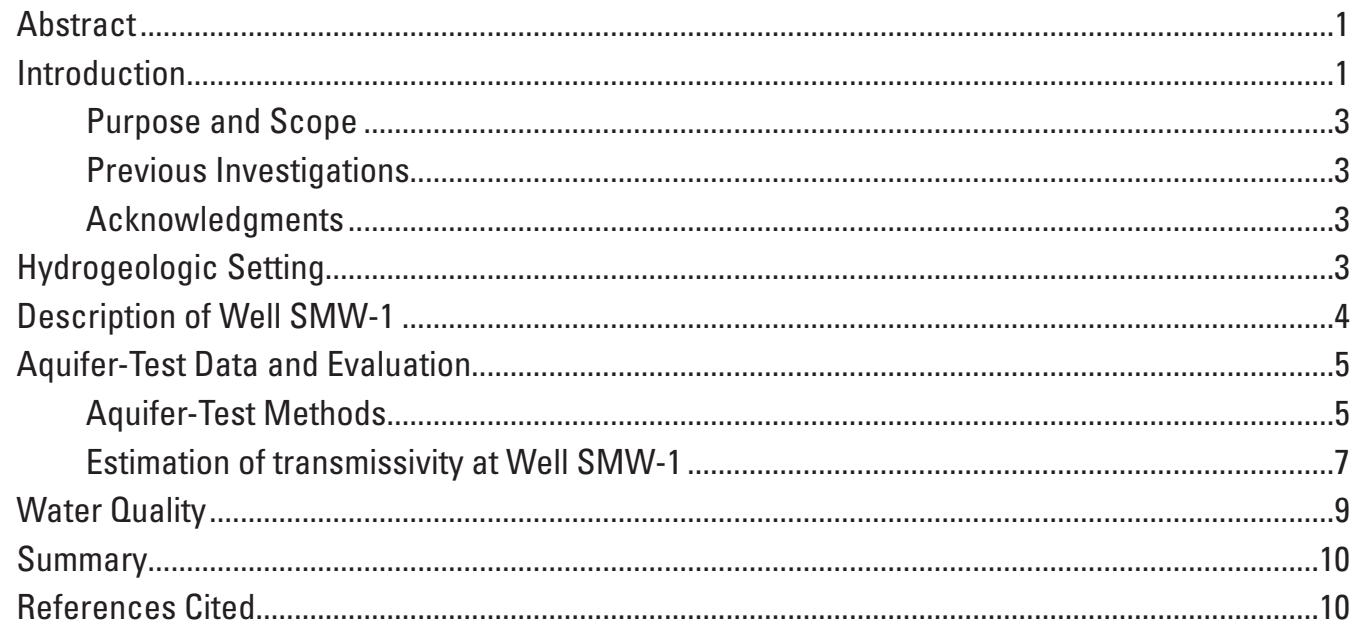

\section{Figures}

1. Map showing the study area near Moenkopi, Arizona ..........................................................

2. Schematic diagram showing estimated construction of SMW-1 near Moenkopi, Arizona......5

3. Graph showing measured water-level drawdown and recovery at SMW-1 during a 9.25-hour step-drawdown test south of Moenkopi, Arizona.............................7

4. Graph showing measured water-level drawdown and recovery at SMW-1 during a 72-hour constant-rate test south of Moenkopi, Arizona ........................................7

5. Graphs showing Cooper-Jacob straight-line method to estimate transmissivity at SMW-1 south of Moenkopi, Arizona; Papadopulos-Cooper method to estimate transmissivity at SMW-1 south of Moenkopi, Arizona; and Theis (recovery) method to estimate transmissivity at SMW-1 south of Moenkopi, Arizona........................8

6. Graphs showing hourly water temperature, specific conductance, $\mathrm{pH}$, and dissolved oxygen during the constant-rate test at SMW-1 south of Moenkopi, Arizona ..................9

\section{Tables}

1. Estimated hydraulic properties for the $\mathrm{N}$ aquifer from SMW-1 south of Moenkopi, Arizona ...7 


\section{Conversion Factors and Datums}

\begin{tabular}{|c|c|c|}
\hline \multicolumn{3}{|c|}{ Inch/Pound to SI } \\
\hline Multiply & $\mathrm{By}$ & To obtain \\
\hline \multicolumn{3}{|c|}{ Length } \\
\hline inch (in.) & 2.54 & centimeter $(\mathrm{cm})$ \\
\hline inch (in.) & 25.4 & millimeter (mm) \\
\hline foot $(\mathrm{ft})$ & 0.3048 & $\operatorname{meter}(\mathrm{m})$ \\
\hline mile (mi) & 1.609 & kilometer $(\mathrm{km})$ \\
\hline \multicolumn{3}{|c|}{ Area } \\
\hline acre & 4,047 & square meter $\left(\mathrm{m}^{2}\right)$ \\
\hline acre & 0.4047 & hectare (ha) \\
\hline acre & 0.004047 & square kilometer $\left(\mathrm{km}^{2}\right)$ \\
\hline square foot $\left(\mathrm{ft}^{2}\right)$ & 0.09290 & square meter $\left(\mathrm{m}^{2}\right)$ \\
\hline square mile $\left(\mathrm{mi}^{2}\right)$ & 2.590 & square kilometer $\left(\mathrm{km}^{2}\right)$ \\
\hline \multicolumn{3}{|c|}{ Volume } \\
\hline gallon (gal) & 3.785 & liter (L) \\
\hline gallon (gal) & 0.003785 & cubic meter $\left(\mathrm{m}^{3}\right)$ \\
\hline cubic foot $\left(\mathrm{ft}^{3}\right)$ & 0.02832 & cubic meter $\left(\mathrm{m}^{3}\right)$ \\
\hline acre-foot (acre-ft) & 1,233 & cubic meter $\left(\mathrm{m}^{3}\right)$ \\
\hline acre-foot (acre-ft) & 0.001233 & cubic hectometer $\left(\mathrm{hm}^{3}\right)$ \\
\hline \multicolumn{3}{|c|}{ Flow rate } \\
\hline foot per minute (ft/min) & 0.3048 & meter per minute $(\mathrm{m} / \mathrm{min})$ \\
\hline foot per day $(\mathrm{ft} / \mathrm{d})$ & 0.3048 & meter per day $(\mathrm{m} / \mathrm{d})$ \\
\hline cubic foot per second $\left(\mathrm{ft}^{3} / \mathrm{s}\right)$ & 0.02832 & cubic meter per second $\left(\mathrm{m}^{3} / \mathrm{s}\right)$ \\
\hline cubic foot per day $\left(\mathrm{ft}^{3} / \mathrm{d}\right)$ & 0.02832 & cubic meter per day $\left(\mathrm{m}^{3} / \mathrm{d}\right)$ \\
\hline gallon per minute (gal/min) & 0.06309 & liter per second $(\mathrm{L} / \mathrm{s})$ \\
\hline gallon per day (gal/d) & 0.003785 & cubic meter per day $\left(\mathrm{m}^{3} / \mathrm{d}\right)$ \\
\hline \multicolumn{3}{|c|}{ Pressure } \\
\hline inch of mercury at $60^{\circ} \mathrm{F}$ (in $\mathrm{Hg}$ ) & 3.377 & kilopascal (kPa) \\
\hline \multicolumn{3}{|c|}{ Specific capacity } \\
\hline gallon per minute per foot $[(\mathrm{gal} / \mathrm{min}) / \mathrm{ft})]$ & 0.2070 & liter per second per meter $[(\mathrm{L} / \mathrm{s}) / \mathrm{m}]$ \\
\hline \multicolumn{3}{|c|}{$\begin{array}{l}\text { Hydraulic conductivity } \\
\end{array}$} \\
\hline foot per day $(\mathrm{ft} / \mathrm{d})$ & 0.3048 & meter per day $(\mathrm{m} / \mathrm{d})$ \\
\hline \multicolumn{3}{|c|}{ Hydraulic gradient } \\
\hline foot per mile (ft/mi) & 0.1894 & meter per kilometer $(\mathrm{m} / \mathrm{km})$ \\
\hline \multicolumn{3}{|c|}{ Transmissivity* } \\
\hline foot squared per day $\left(\mathrm{ft}^{2} / \mathrm{d}\right)$ & 0.09290 & meter squared per day $\left(\mathrm{m}^{2} / \mathrm{d}\right)$ \\
\hline \multicolumn{3}{|c|}{ Leakance } \\
\hline foot per day per foot $[(\mathrm{ft} / \mathrm{d}) / \mathrm{ft}]$ & 1 & meter per day per meter \\
\hline inch per year per foot [(in/yr)/ft] & 83.33 & millimeter per year per meter $[(\mathrm{mm} / \mathrm{yr}) / \mathrm{m}]$ \\
\hline
\end{tabular}

\footnotetext{
Temperature in degrees Celsius $\left({ }^{\circ} \mathrm{C}\right)$ may be converted to degrees Fahrenheit $\left({ }^{\circ} \mathrm{F}\right)$ as follows: ${ }^{\circ} \mathrm{F}=\left(1.8 \times{ }^{\circ} \mathrm{C}\right)+32$

Temperature in degrees Fahrenheit $\left({ }^{\circ} \mathrm{F}\right)$ may be converted to degrees Celsius $\left({ }^{\circ} \mathrm{C}\right)$ as follows: ${ }^{\circ} \mathrm{C}=\left({ }^{\circ} \mathrm{F}-32\right) / 1.8$

*Transmissivity: The standard unit for transmissivity is cubic foot per day per square foot times foot of aquifer thickness $\left[\left(\mathrm{ft}^{3} / \mathrm{d}\right) / \mathrm{ft}^{2}\right] \mathrm{ft}$. In this report, the mathematically reduced form, foot squared per day $\left(\mathrm{ft}^{2} / \mathrm{d}\right)$, is used for convenience.

Specific conductance is given in microsiemens per centimeter at 25 degrees Celsius $\left(\mu \mathrm{S} / \mathrm{cm}\right.$ at $\left.25^{\circ} \mathrm{C}\right)$.

Concentrations of chemical constituents in water are given either in milligrams per liter $(\mathrm{mg} / \mathrm{L})$ or micrograms per liter $(\mu \mathrm{g} / \mathrm{L})$.
} 


\title{
Aquifer Test at Well SMW-1 near Moenkopi, Arizona
}

\author{
By Robert L. Carruth and Donald J. Bills
}

\section{Abstract}

The Hopi villages of Lower Moencopi and Upper Moenkopi are on the Hopi Indian Reservation south of Tuba City in northern Arizona. These adjacent Hopi villages, located west and north of the confluence of Pasture Canyon Wash and Moenkopi Wash, are dependent on groundwater withdrawals from three wells that penetrate the $\mathrm{N}$ aquifer and from two springs that discharge from the $\mathrm{N}$ aquifer. The $\mathrm{N}$ aquifer is the principal aquifer in this region of northern Arizona and is composed of thick beds of sandstone between less permeable layers of siltstone and mudstone. The finegrained character of the $\mathrm{N}$ aquifer inhibits rapid movement of water and large yields to wells; however, the aquifer is moderately productive at yields generally less than 25 gallons per minute in the study area. In recent years, the water level has declined in the three public-supply wells and the flow from the springs has decreased, causing concern that the current water supply will not be able to accommodate peak demand and allow for residential and economic growth. In addition to the challenge imposed by declining groundwater levels, the water-supply wells and springs are located about 2 miles downgradient from the Tuba City Landfill site where studies are ongoing to determine if uranium and other metals in groundwater beneath the landfill are higher than regional concentrations in the $\mathrm{N}$ aquifer. In August 2008, the U.S. Geological Survey, in cooperation with the Hopi Tribe, conducted an aquifer test on well SMW-1, designed to help the Hopi Tribe determine the potential yield and water quality of the $\mathrm{N}$ aquifer south of Moenkopi Wash as a possible source of additional water supply.

Well SMW-1 was drilled south of Moenkopi Wash to a depth of 760 feet below land surface before being backfilled and cased to about 300 feet. The well penetrates, in descending order, the Navajo Sandstone and the Kayenta Formation, both units of the $\mathrm{N}$ aquifer. The pre-test water level in the well was 99.15 feet below land surface. A 9.25-hour step-drawdown test and a 72-hour constant-rate test followed by recovery tests were used to investigate the performance of the test well and to estimate the transmissivity and potential yield of the $\mathrm{N}$ aquifer south of Moenkopi Wash. The test data were analyzed using the Cooper-Jacob method adjusted for confined conditions, the Papadopulos-Cooper method that accounts for wellbore storage, and the Theis method on the recovery data. Results of the tests indicate that in the vicinity of the well, the
$\mathrm{N}$ aquifer has a transmissivity of about 50 feet squared per day. The test well, as completed, should yield about 15 gallons per minute with about 75 feet of drawdown (less than half of the available saturated thickness of the aquifer at the well).

\section{Introduction}

In recent years, the public water supply for residents of the Hopi villages of Lower Moencopi and Upper Moenkopi on the Hopi Indian Reservation near Tuba City (collectively referred to as the Moenkopi villages), Arizona, has been insufficient to meet peak demand (fig. 1). Additionally, residents are concerned that the limited water supply will prevent future economic and residential growth. The water supply for these villages is groundwater withdrawn from three wells that penetrate the $\mathrm{N}$ aquifer (MSW-1, MSW-2, and MSW-3) and from two springs that discharge from the $\mathrm{N}$ aquifer (fig. 1).

Water levels in the three public-supply wells serving the villages have declined several tens of feet in recent years (U.S. Department of Health and Human Services, 2008). Additionally, the close spacing of the three wells leads to additional drawdown and decreased production from well interference when the wells are operated simultaneously. As a result, the water level in the wells approaches the pump intakes during continuous pumping - forcing water operators to rotate the operation of the pumps on a nearly daily basis. Discharge from MSW-3 has declined from about 40 to less than 10 gallons per minute (gal $/ \mathrm{min}$ ) when pumping is continuous in conjunction with the operation of either MSW-1 or MSW-2. The pumping water levels in MSW-1 and MSW-2 have declined several tens of feet and discharge from the wells ranges from about 25 to $40 \mathrm{gal} / \mathrm{min}$ when operation of the pumps is rotated. The discharge from one spring developed for water supply has also declined in recent years and another spring has gone dry (U.S. Department of Health and Human Services, 2008).

The $\mathrm{N}$ aquifer is a regional and moderately productive groundwater-flow system that underlies most of the Navajo and Hopi Indian Reservations in northern Arizona. The Moenkopi villages, however, are located at the western edge of the $\mathrm{N}$ aquifer where the permeable rocks of the $\mathrm{N}$ aquifer are thinned by exposure and erosion or locally pinch out. Groundwater withdrawal in the Moenkopi and Tuba City 


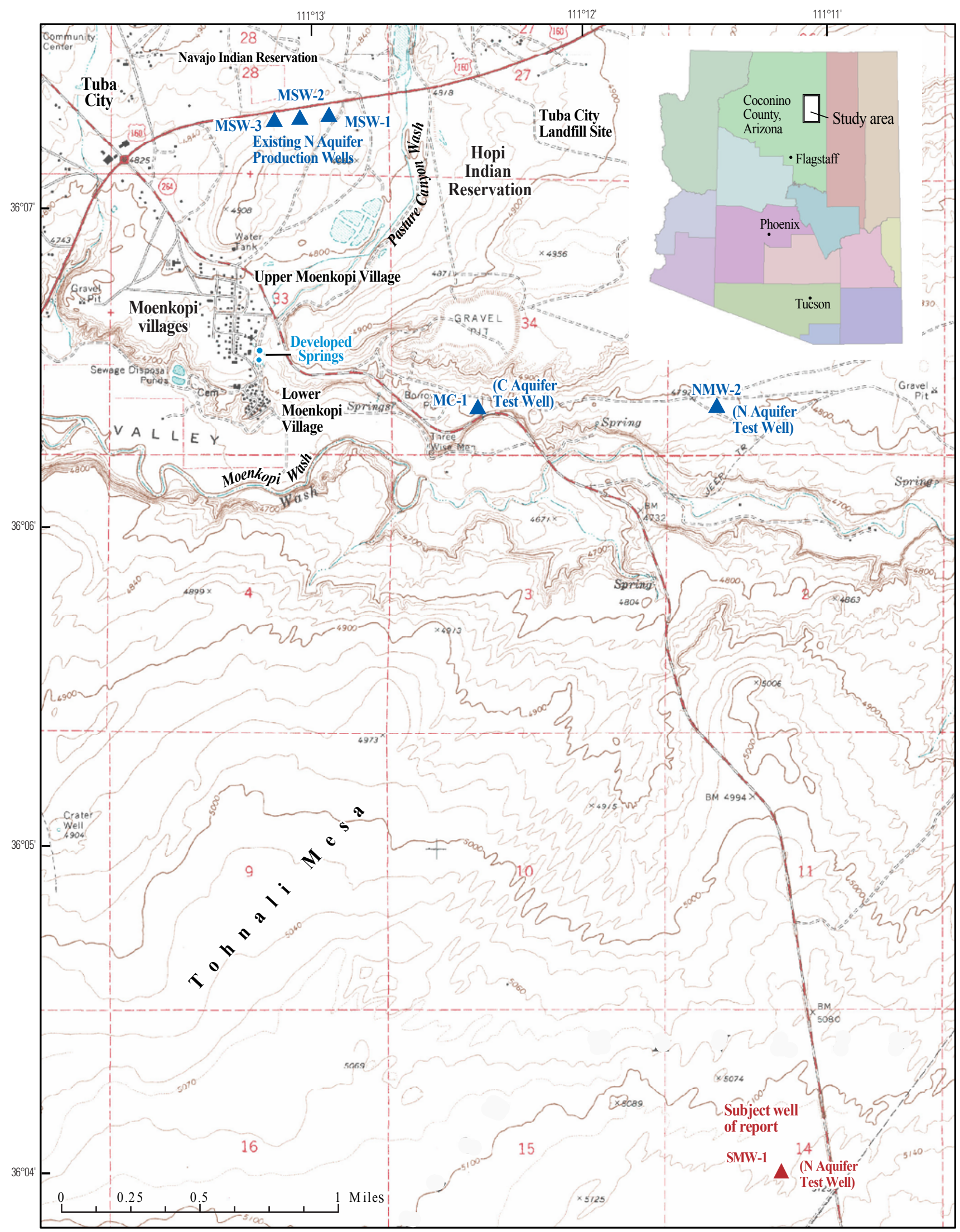

Base from U.S. Geological Survey digital data, 1969 Moenkopi quadrangle digital raster graphic

Figure 1. Map showing the study area near Moenkopi, Arizona. 
area in excess of natural recharge may be dewatering the aquifer locally. Additionally, the public-supply wells and springs for the Moenkopi villages are located about 2 miles (mi) downgradient from the Tuba City Landfill site where studies are ongoing to determine if uranium and other metals in groundwater beneath the landfill are above regional concentrations in the $\mathrm{N}$ aquifer.

The Hopi Tribe has drilled at least three wells near the villages to explore the potential for additional groundwater resource development south of Moenkopi Wash that could augment the current water supply (Tetra Tech EM Inc., 2004). Two wells were drilled in the N aquifer (SMW-1 and NMW-2) and a third, deeper well (MC-1) was drilled in the $\mathrm{C}$ aquifer (fig. 1). Aquifer tests are needed to determine the optimal pumping rates and aquifer hydraulic properties in the vicinity of these wells. The $\mathrm{C}$ aquifer well, $\mathrm{MC}-1$, has a total dissolved solids (TDS) concentration of about 3,600 milligrams per liter ( $\mathrm{mg} / \mathrm{L})$; consequently, the Hopi Tribe has approved construction of a reverse osmosis plant to treat the water. Questions remain, however, about the quality and quantity of water that could be produced in the two $\mathrm{N}$ aquifer wells and the $\mathrm{C}$ aquifer well, and whether the water quality and quantity could degrade or decrease with pumping over time. The Hopi Tribe also is concerned that continued pumping of the existing supply wells with additional pumping of new wells might result in more rapid groundwater level decline and migration of potential contaminants from the Tuba City Landfill site to the village wells and springs. The Indian Health Service (IHS) and the Hopi Tribe have asked for assistance from the U.S. Geological Survey (USGS) to evaluate sources of water supply and its quality as it relates to the migration of potentially contaminated groundwater to water-supply wells and springs for groundwater resources in the Moenkopi area.

This report describes on-site monitoring and analysis of a single-well aquifer test of the South Moenkopi Wash-1 well (SMW-1). Well SMW-1 is located about 3 mi south of the Moenkopi Villages and $0.15 \mathrm{mi}$ west of SR 264 (fig.1). The test hole was drilled to a total depth of 760 feet (ft), penetrating $280 \mathrm{ft}$ of Navajo Sandstone and $480 \mathrm{ft}$ of Kayenta Formation (Tetra Tech EM Inc., 2004). The completed test well was backfilled and cased to $300 \mathrm{ft}$; the well is screened from about 200 to $300 \mathrm{ft}$.

The IHS and the Hopi Tribe requested the aquifer test at SMW-1 as a means of addressing the immediate need for additional water supply. Evaluation of the single-well aquifertest data from SMW-1 will provide the IHS and the Hopi Tribe with a better understanding of the aquifer hydraulic properties and sustainable well yield from the $\mathrm{N}$ aquifer south of Moenkopi Wash - meeting the need to determine if this area has potential for development of additional public water supply. The area south of Moenkopi Wash also is under consideration for expanded community development for the village of Lower Moencopi. The information in this report is intended to complement a more comprehensive hydrogeologic study for the area surrounding both villages that the IHS and the Hopi Tribe could use to guide development of additional public water supply and protect limited groundwater resources.

\section{Purpose and Scope}

This report presents data and analysis for a single-well aquifer test at well SMW-1. The data collection and analysis were conducted in cooperation with the Hopi Tribe. This report describes the drilling and construction information for the test well and the hydrogeologic setting. Data collected for this study include pumping rates and water-level drawdown and recovery during a 9.25-hour step-drawdown test and a 72-hour constant-rate test. Additional field parameter data are presented including water temperature, specific conductance, $\mathrm{pH}$, and dissolved oxygen. The report also describes a graphical evaluation of the aquifer test data. Well construction information, pumping rates, and drawdown and recovery data provide the information needed for the aquifer-test analysis and for the estimation of the optimal pumping rate for the well.

\section{Previous Investigations}

The $\mathrm{N}$ aquifer has been previously investigated to evaluate water availability for local needs. A study by Cooley and others (1969) provided the regional hydrogeologic characterization of the $\mathrm{N}$ aquifer in the Moenkopi and Tuba City area. Additional investigations by the USGS have added to this characterization over the years (Levings and Farrar, 1977; Farrar, 1977; Eychaner, 1983; Lopes and Hoffmann, 1997; Hoffmann and others, 2006; Macy, 2009). Additional studies have characterized the aquifer at the scale of individual test wells (Tetra Tech EM Inc., 2004). Local geology and geologic structure also has been investigated (J.P. Macy, USGS, oral commun., Jan. 2011) and is of importance as it affects the occurrence and movement of groundwater and movement of potential contaminants in the area.

\section{Acknowledgments}

We thank Sharon Masek Lopez, Hopi Water Resources Program, who contracted for the aquifer test at well SMW-1 and Beeman Brothers, the drilling contractor responsible for the operation and maintenance of the pump during the test. We also wish to acknowledge Hopi Water Resources Program technicians Avery Pavinyama, Marlin Silas, and Yolanda Nasoftie for providing onsite support for the duration of the aquifer test.

\section{Hydrogeologic Setting}

Well SMW-1 is located on the Tohnali Mesa south of Moenkopi Wash, about $0.15 \mathrm{mi}$ west of SR 264, and about 3 mi south of the Moenkopi villages as previously stated (fig.1). 
Exposed rocks at the test site include Navajo Sandstone and drift sand and dunes eroded from the Navajo Sandstone. The surface deposits are covered with sparse desert grasses, cactus, and sage brush. The regional dip of rock units at the surface is about 2 degrees to the northeast toward the Tuba City syncline located about $8 \mathrm{mi}$ from the test site (Cooley and others, 1969). There are no other geologic structures recognizable at the surface of the well site.

The Navajo Sandstone and Kayenta Formation were the only major geologic units penetrated during the drilling of well SMW-1. These two units comprise the $\mathrm{N}$ aquifer and are described here in descending stratigraphic order. The Navajo Sandstone is an orange-red to red, fine-grained, and crossbedded sandstone. The Navajo Sandstone is as much as 1,300 $\mathrm{ft}$ thick to the south and southeast of SMW-1 on Moenkopi Plateau but thins rapidly from a few hundred feet to a few tens of feet at the western, north, and northwestern edges of Tohnali Mesa and west of Tuba City (Cooley and others, 1969; Farrar, 1977).

The Kayenta Formation is a series of interbedded and thinly cross-bedded, red to dark red sandstone, siltstone, and mudstone up to $700 \mathrm{ft}$ thick in the study area. Interbedding of the Navajo Sandstone with the finer grained Kayenta Formation in the Moenkopi/Tuba City area can create confining conditions, causing the water in a well drilled into the Navajo Sandstone to rise several feet, in some cases flowing at land surface (Cooley and others, 1969; Farrar, 1977). In recent years, however, groundwater pumping for municipal water supply has reduced much of this artesian (confined) pressure (Macy, 2009).

The Navajo Sandstone is the primary water-bearing unit of the $\mathrm{N}$ aquifer in the Moenkopi and Tuba City area (Cooley and others, 1969; Farrar, 1977). At Tuba City, the N aquifer is fully to partially saturated and in some areas confined because of interfingered relatively impermeable sediments of the Kayenta Formation with the Navajo Sandstone. The Kayenta Formation also is partly to fully saturated in the Moenkopi and Tuba City area and hydraulically connected to the Navajo Sandstone. Siltstone, sandy siltstone, and sandstone layers of the Kayenta Formation yield small amounts of generally poorer (higher TDS concentration than water from the Navajo Sandstone) quality water to wells in the area. Lithographic and erosional thinning of the $\mathrm{N}$ aquifer south and west of Moenkopi and Tuba City has reduced the saturated thickness and yield characteristics of the aquifer locally.

About 40 springs and seeps issue from cliff faces of Moenkopi Wash in the vicinity of the Moenkopi villages (Arizona Department of Water Resources, 2008). More than 30 of these springs (ranging in discharge from less than 1 to over $15 \mathrm{gal} / \mathrm{min}$ ) issue from the Navajo Sandstone and interfingered sediments of the Navajo Sandstone with the Kayenta Formation on south facing cliffs of Moenkopi Wash. This suggests that the sediments of the Navajo Sandstone are more permeable than Kayenta Formation sediments north of the Moenkopi Wash. In contrast, fewer than 10 springs issue from the north facing cliffs of Moenkopi Wash (the north edge of Tohnali Mesa) and generally discharge less than 3 $\mathrm{gal} / \mathrm{min}$ from the base of the Navajo Sandstone, suggesting poorer water-bearing properties of the $\mathrm{N}$ aquifer south of the Moenkopi Wash. Water level measurements at wells drilled on the Tohnali Mesa portion of the Moenkopi Plateau south of Moenkopi Wash indicate depths to water of $200 \mathrm{ft}$ or more. Well yields generally are less than $3 \mathrm{gal} / \mathrm{min}$ (Cooley and others, 1969; Levings and Farrar, 1977).

\section{Description of Well SMW-1}

As stated previously, rock units identified in the drill cuttings from well SMW-1 are the Navajo Sandstone and the Kayenta Formation. Thickness of the Navajo Sandstone at well SMW-1 is about $280 \mathrm{ft}$. The cuttings from the Navajo Sandstone are white to pink and light reddish brown, well sorted, fine to very fine-grain quartz sand, slightly cemented to friable with calcareous material (Tetra Tech EM Inc., 2004). A gradual transition from mainly Navajo Sandstone to the underlying Kayenta Formation is indicated by alternating reddish-brown sandstone with pinkish-white siltstone over the depths of 220 to $340 \mathrm{ft}$. The well penetrates the upper $480 \mathrm{ft}$ of Kayenta Formation, which has been estimated to be approximately $750 \mathrm{ft}$ thick at the well (Cooley and others, 1969). Cuttings of Kayenta Formation from well SMW-1 are described as a sequence of interbedded reddish-brown siltstones and sandstones. The siltstone is reddish brown, moderately well sorted, occasionally sandy with quartz sand, and well cemented with calcareous material (Tetra Tech EM Inc., 2004). The sandstone consists largely of reddishbrown silt to very fine quartz sand that is well cemented with calcareous material. Toward the bottom of the test hole small amounts of feldspar and biotite are more prominent in the sandstone layers. Based on the cuttings description these sandstone layers in the Kayenta Formation are not interfingered facies of the Navajo Sandstone.

Well SMW-1 was drilled as part of a program developed by the Hopi Tribe and Bureau of Reclamation (BOR) to evaluate water quality and potential well yield of the Navajo Sandstone and the Kayenta Formation south of Moenkopi Wash (Hopi Tribe, 2003). Well SMW-1 is one of two test wells in the $\mathrm{N}$ aquifer. The other well, North Moenkopi Wash well 2 (NMW-2) is located about $1.75 \mathrm{mi}$ east of Lower Moencopi (fig. 1). Well SMW-1 was drilled and developed by Beeman Brothers Drilling. Tetra Tech EM Inc. (2004) oversaw initial development and testing of the well and documented the results in a series of reports issued in the fall of 2004. Tetra Tech (2004) logged the cuttings from the well every $10 \mathrm{ft}$ and evaluated a suite of geophysical logs including deviation, gamma, temperature, caliper, self potential, resistivity, electromagnetic, and neutron density.

Well SMW-1 was drilled on February 24-25, 2004; the driller used a hammer bit and standard rotary methods with air, water, and foam. To stabilize the upper part of the hole, $40 \mathrm{ft}$ of 10 -in. steel surface casing was emplaced and included 
$2.8 \mathrm{ft}$ of riser above the surface. All logs and borehole tests were conducted in the open hole to $760 \mathrm{ft}$. Zonal tests by Tetra Tech EM Inc. (2004) of the SMW-1 well were conducted using airlift methods to investigate the water-level response and to collect water samples from four water-bearing zones encountered in the test hole. Three of these zones were in the Kayenta Formation from depths of 650 to $718 \mathrm{ft}, 511$ to $583 \mathrm{ft}$, and 356 to $427 \mathrm{ft}$. One of the zones was in the Navajo Sandstone and Navajo Sandstone/Kayenta Formation transition zone from depths of 247 to $291 \mathrm{ft}$. Water from each zone was airlifted for about 8 hours and at the end of the period, a water sample was collected for chemical analysis. Only the upper part of the Kayenta Formation (depths of 356 to $427 \mathrm{ft}$ ) and the Navajo Sandstone yielded a sufficient quantity of water for the collection of water samples. Airlift discharge rates were $4 \mathrm{gal} / \mathrm{min}$ or less for the duration of the tests with the Navajo Sandstone producing the higher flow rates. According to Tetra Tech EM Inc. (2004), the total dissolved solids (TDS) concentrations were $610 \mathrm{mg} / \mathrm{L}$ in water samples from the upper Kayenta Formation zone and 220 $\mathrm{mg} / \mathrm{L}$ in water samples from the Navajo Sandstone.
TetraTech EM Inc. (2004) provided the Hopi Tribe with a recommended well completion schedule for the test hole, but the final well construction details were not available before the aquifer test. Based on field observations during the aquifer test and conversations with the driller from Beeman Brothers Drilling, it is likely the well was constructed as follows (fig. 2): After the zone testing was completed, the hole was left idle for an unknown period of time before being completed. On completion, the hole was backfilled with material that came out of the hole and local sand to a depth of about $300 \mathrm{ft}$. Fiveinch outside diameter (OD), 4-inch (in.) inside diameter (ID), PVC (polyvinyl chloride) casing was installed from $2.5 \mathrm{ft}$ above land surface to about $300 \mathrm{ft}$ below land surface with a $100-\mathrm{ft}$ screened interval from about 200 to $300 \mathrm{ft}$. The well screen is likely schedule 40 slotted PVC. The well was gravel packed with graded sand and grout sealed at the surface (Todd Beeman, Beeman Brothers Drilling, oral commun., July 2008). There is no static water-level information from before or after the zone tests or after well completion. On July 5, 2008 , one month before the aquifer test, the static water level in the well was $98.5 \mathrm{ft}$ below land surface.

\section{Aquifer-Test Data and Evaluation}

\section{Aquifer-Test Methods}

A single-well aquifer test was conducted at well SMW-1 in August 2008 to estimate potential well yield and transmissivity of the $\mathrm{N}$ aquifer in the vicinity of the well. The test included a step-drawdown test and a constant-rate test. The next closest well to well SMW-1 is over $2 \mathrm{mi}$ to the northwest, which is too far away to use as an observation well given the length of the test and the anticipated pumping rates (fig. 1). The step-drawdown test was used to determine the pumping rate for the constant-rate test. The constant-rate test was used to provide estimates of transmissivity and yield for the well. Recovery data from the constant-rate test were used to provide another estimate of transmissivity. The stepdrawdown test was planned for 12 hours with about 24 hours of monitored recovery; however, the pump was shut off after about 9 hours and 15 minutes when drawdown in the well (at a pumping rate of $30 \mathrm{gal} / \mathrm{min}$ ) reached the bottom of the sounding tube, preventing further water-level measurements. After recovery from the step-drawdown test, the 72-hour constant-rate test was planned with about a 78-hour monitored recovery period. About one month prior to the aquifer tests, static water-level data from the well were collected once per day, 3 to 5 days per week. The pre-pumping static water level ranged from 98.39 to $100.4 \mathrm{ft}$ below land surface and averaged $99.15 \mathrm{ft}$. On July 30th a submersible pump with 2-in. column pipe and a $3 / 4-$ in. sounding line were installed in the well.

The well was instrumented with a pressure transducer and data logger (miniTROLL ${ }^{\circledR}$, In-Situ Inc.) in the sounding

Figure 2. Schematic diagram showing estimated construction of SMW-1 near Moenkopi, Arizona. 
line on August 5th that measured water level and temperature every second for 21 hours - until just before the start of the step-drawdown test on August 6, 2008, at 1400 hours Mountain Standard Time (MST). Based on these measurements, the static water level leading up to the stepdrawdown test averaged $99.35 \mathrm{ft}$ below land surface and varied about plus or minus $0.1 \mathrm{ft}$. During both the stepdrawdown test and the constant-rate test, the transducer logged water level and temperature data every second. The transducer had a pressure range of $100 \mathrm{ft}$ and had to be periodically lowered and raised in the well during the test and recovery periods to avoid exceeding the stated range. Check measurements were made in the sounding line using a calibrated electric tape (Solinst Model 101) at least every hour for the duration of the test and recovery periods. Check measurements were made more frequently near the beginning of the pumping periods and at the start of the recovery periods.

Barometric pressure data were obtained from the Tuba City Weather Station for the period of August 8-15, to adjust for barometric effects, if necessary. Barometric pressure varied over a narrow range from 24.53 to 24.78 inches of mercury during the test period and no corresponding waterlevel change was noted; thus, no adjustments to the waterlevel data were necessary.

Well discharge was measured with a Rockwell totalizing inline flow meter installed about $4 \mathrm{ft}$ from the wellhead in a 2 -in. discharge line. At the end of the 2-in. steel discharge line, the discharge was checked volumetrically with a 50-gallon (gal) plastic barrel. Prior to the test, the volume of the barrel was checked with a calibrated 5-gal plastic bucket. A 3-in. modified Parshall flume was installed about $20 \mathrm{ft}$ downstream from the end of the discharge line as an independent check measurement of discharge from the well. For both tests the water was channeled to a stock pond about $300 \mathrm{ft}$ east of the pumping well — very little of the pumped water accumulated in the stock pond. Most of the water infiltrated into the loose surface sand and (or) evaporated. There is a small possibility that the discharged water could have recharged the aquifer during the test, but it is not likely given the short duration of the test and other site conditions.

During the step-drawdown test and the constant-rate test, the well-discharge water was tested hourly for temperature, specific conductance, $\mathrm{pH}$, and dissolved oxygen with a Hydrolab Quanta multimeter. These basic field waterquality parameters were collected during the tests because well SMW-1 may be evaluated for an additional source of water supply in the future - evaluation of the data will help determine if poorer quality water from the underlying Kayenta Formation (higher TDS concentration than water from the Navajo Sandstone) moves upward into the well under pumping conditions.

Water-level drawdown (displacement) in the well was estimated by subtracting the water levels measured during the aquifer test from the average water level measured before pumping began. As stated previously, no adjustments for barometric, earth-tide, or regional effects were made to measured water levels before drawdowns were estimated. The data provided in this report are the corrected drawdown values used in the aquifer-test analysis.

The well construction information, pumping rates, and drawdown and recovery data provide the needed input for the aquifer test analysis. The transmissivity of the $\mathrm{N}$ aquifer in the vicinity of the test well was estimated by using the aquifer-test software AQTESOLV, Version 4.50 Professional (Duffield, 2007), which includes a number of analytical solutions to drawdown and discharge data. Specific capacity was determined from the drawdown and discharge data for both the step-drawdown and constant-rate tests. Using the aquifer-test software, transmissivity was estimated independently using (1) the Cooper-Jacob method adjusted for confined conditions (Cooper and Jacob, 1946), (2) the Papadopulos-Cooper method which accounts for wellbore storage (Papadopulos and Cooper, 1967), and (3) the Theis method on the recovery data (Theis, 1935). The methods used to analyze the aquifer test data, and their limitations, also are described in Kruseman and de Ridder (1994). The sustainable yield and well spacing estimates are based on their proportional relation to the aquifer properties, the discharge rate of the well, the drawdown data, and the length of the pumping period.

The process of drilling a well affects the permeability of the aquifer in the immediate vicinity of the borehole. This is referred to as "skin effect" (Driscoll, 1986). At the beginning of a pumping period, the water level can fluctuate significantly in response to the changes in local permeability and pumping. These fluctuations create noise in the waterlevel record that add complexity to evaluation of single-well aquifer tests. In addition, wellbore storage in the pumping well affects water levels at the beginning of the aquifer test. As a result, water-level data from a pumping well generally are less desirable for analysis of aquifer properties than data from observation wells located some distance from the pumping well. Pumping-well data are useful, however, for estimating transmissivity in the absence of observation wells. The recovery data for single-well tests are more useful since these data are not subject to the same borehole effects caused during pumping of the well.

The step-drawdown test was conducted on well SMW-1 on August 6th starting at 1432 MST (fig. 3). The initial pumping rate was $10 \mathrm{gal} / \mathrm{min}$ with two additional steps at 20 and $30 \mathrm{gal} / \mathrm{min}$. The drawdown at $10 \mathrm{gal} / \mathrm{min}$ was reasonably stable after 275 minutes of pumping and the discharge rate was increased to $20 \mathrm{gal} / \mathrm{min}$. At 525 minutes the drawdown was reasonably stable and the discharge rate was increased to $30 \mathrm{gal} / \mathrm{min}$. At 555 minutes the drawdown reached the end of the sounding tube at a depth of $255 \mathrm{ft}$ and depth-to-water measurements could no longer be measured. At 2300 MST on August 6th at 556 minutes, the pump was shut off and recovery began. After 1,395 minutes at 1300 MST on August 7th, the water level in the well had recovered to $102.8 \mathrm{ft}$ or 97 percent of the original static water level. 
The selected pumping rate for the constant-rate test was $20 \mathrm{gal} / \mathrm{min}$, based on the reasonably stable drawdown at that rate during the step-drawdown test. The constant-rate test started at 1330 MST on August 7th and ended 71.6 hours later on August 10th at 1200 MST (fig. 4) with a maximum drawdown of $123.2 \mathrm{ft}$. The recovery period lasted for about 78 hours when the static water level in the well had recovered to $104.6 \mathrm{ft}$ or 98 percent of the pretest static water level. Total water pumped from the well during both the step-drawdown test and the constant-rate test was 94,650 gallons.

\section{Estimation of transmissivity at Well SMW-1}

As stated previously, aquifer transmissivity values were estimated from the well data based on the Cooper-Jacob, Papadopulos-Cooper, and Theis (recovery) methods adjusted for both confined and unconfined conditions (figs $5 A-C$; Driscoll, 1986). The adjustment for unconfined conditions involved using the pre-pumping saturated thickness of the aquifer in place of the well function in the calculation of transmissivity. Transmissivity estimated from the constant rate

Table 1. Estimated hydraulic properties for the $\mathrm{N}$ aquifer from SMW-1 south of Moenkopi, Arizona

$\left[(\mathrm{gal} / \mathrm{min}) / \mathrm{ft}\right.$, gallons per minute per foot of drawdown; $\mathrm{ft}^{2} / \mathrm{d}$, foot squared per day; $\mathrm{ft} / \mathrm{d}$, foot per day; $\mathrm{NC}$, not calculated; $\mathrm{ft}-1$, per foot. Specific-capacity values were determined during constant-rate aquifer test]

\begin{tabular}{lll}
\hline Hydraulic property & SMW-1 & Regional values $^{2}$ \\
\hline Specific capacity & 0.16 to $0.20(\mathrm{gal} / \mathrm{min}) / \mathrm{ft}$ & 0.74 to $3.24(\mathrm{gal} / \mathrm{min}) / \mathrm{ft}$ \\
Transmissivity (Cooper-Jacob) & $50 \mathrm{ft}^{2} / \mathrm{d}$ & 20 to $800 \mathrm{ft}^{2} / \mathrm{d}$ \\
$\begin{array}{l}\text { Transmissivity (Papadopulous-Cooper) } \\
\text { Transmissivity (Theis-Recovery) }\end{array}$ & $53 \mathrm{ft}^{2} / \mathrm{d}$ & \\
Hydraulic conductivity & & 0.05 to $2.1 \mathrm{ft} / \mathrm{d}$ \\
Aquifer thickness at the well & $200^{3} \mathrm{ft}$ & \\
Estimated pumping rate & $15^{1} \mathrm{gpm}$ & 15 to $150 \mathrm{gpm}$ \\
\hline
\end{tabular}

lat $75 \mathrm{ft}$ drawdown

${ }^{2}$ Coole and others, 1969 and Eychaner, 1983

${ }^{3}$ pre-test water level $99.15 \mathrm{ft}$ below land surface

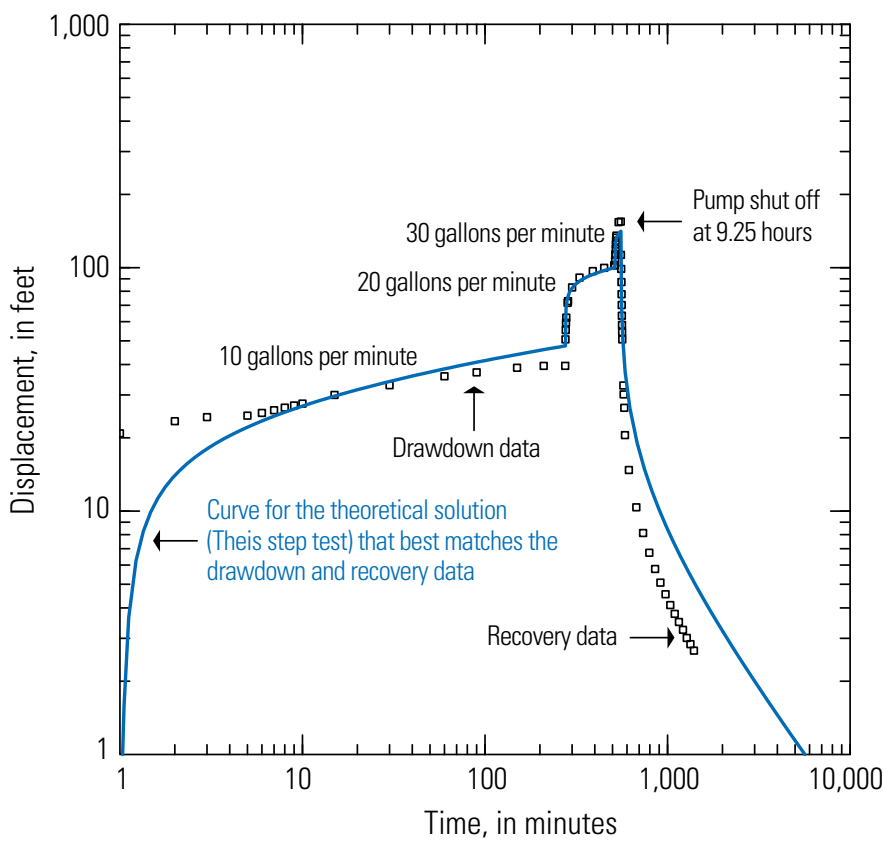

Figure 3. Graph showing measured water-level drawdown and recovery at SMW-1 during a 9.25-hour step-drawdown test south of Moenkopi, Arizona.

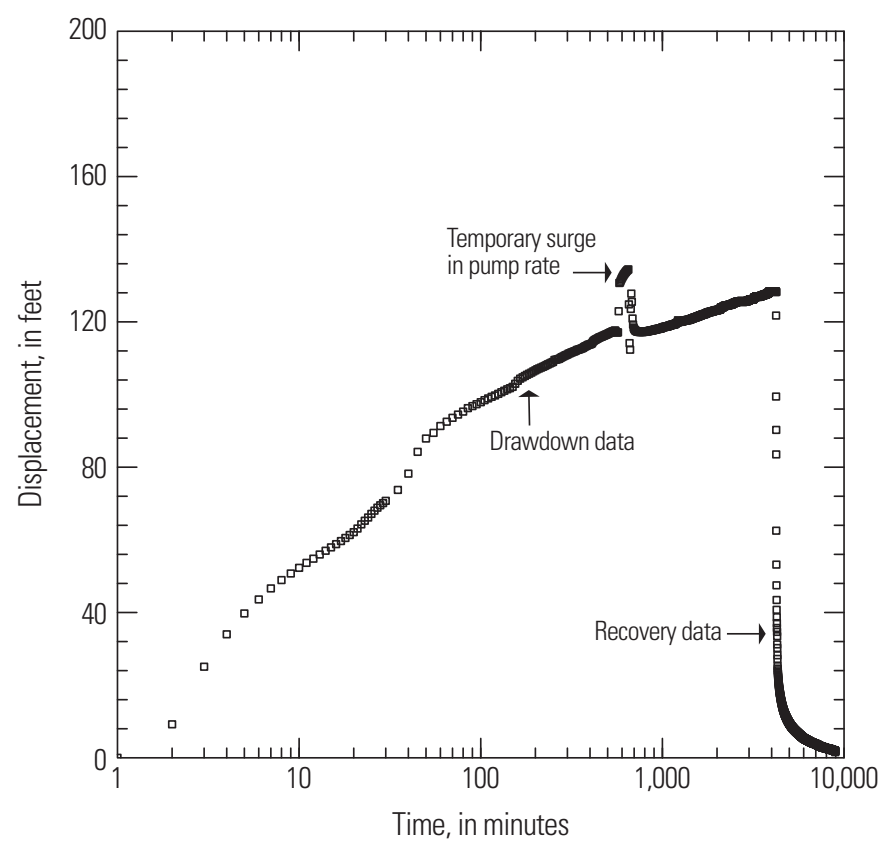

Figure 4. Graph showing measured water-level drawdown and recovery at SMW-1 during a 72-hour constant-rate test south of Moenkopi, Arizona. 


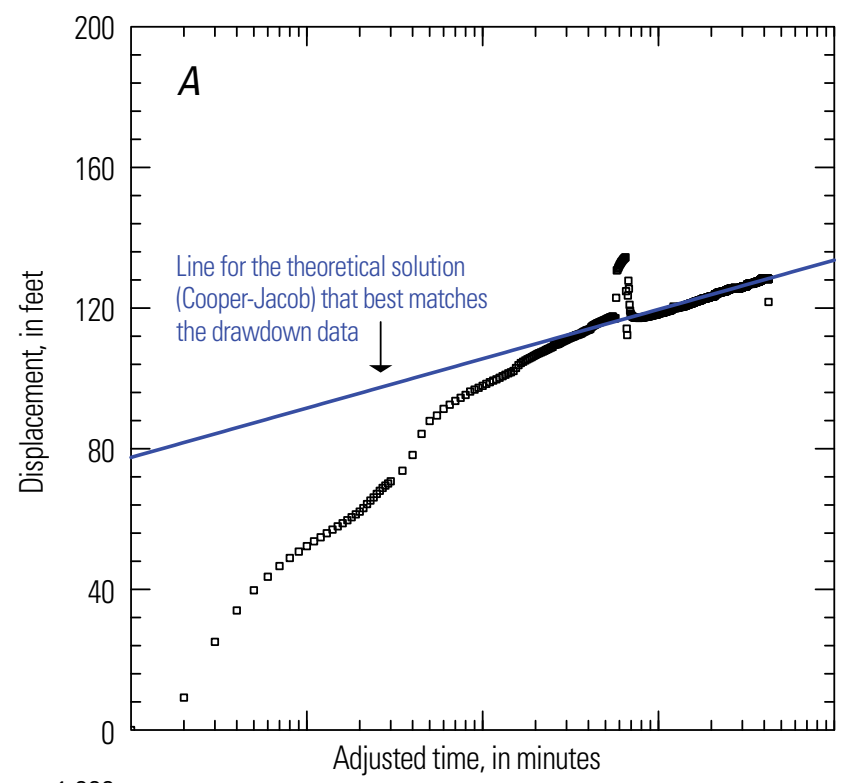

\section{Explanation \\ Solution method: \\ Cooper-Jacob \\ Aquifer model: \\ Confined \\ Transmissivity = \\ 50.29 feet squared per day}

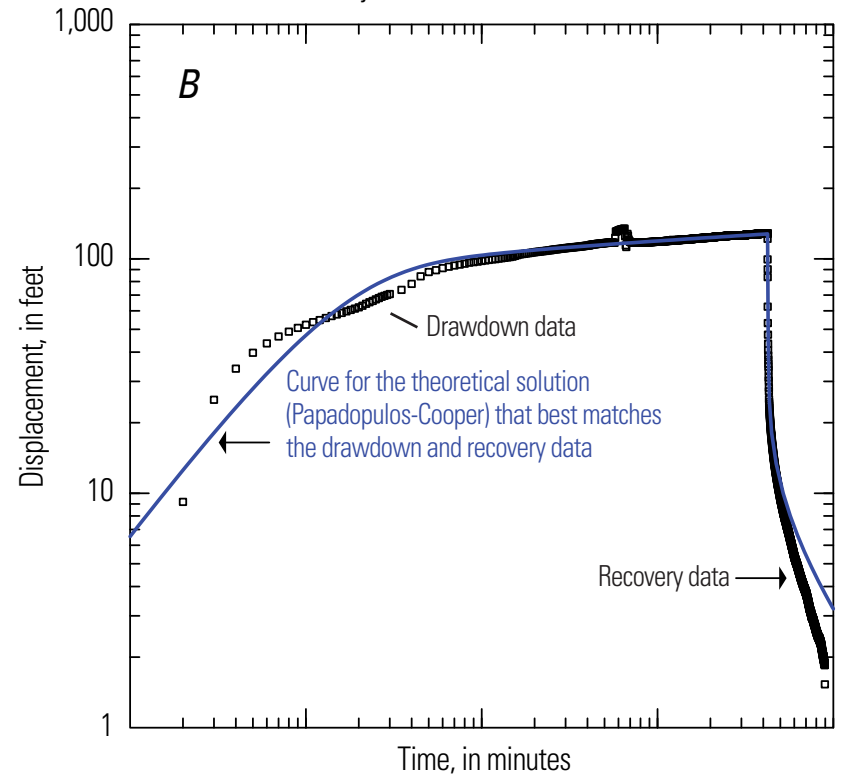

Explanation

Solution method:

Papadopulos-Cooper

Aquifer model:

Confined

Transmissivity $=$

52.73 feet squared per day

Figure 5. A, Graph showing CooperJacob straight-line method to estimate transmissivity at SMW-1 south of Moenkopi, Arizona. B, Graph showing PapadopulosCooper method to estimate transmissivity at SMW-1 south of Moenkopi, Arizona. $C$, Graph showing Theis (recovery) method to estimate transmissivity at SMW-1 south of Moenkopi, Arizona.

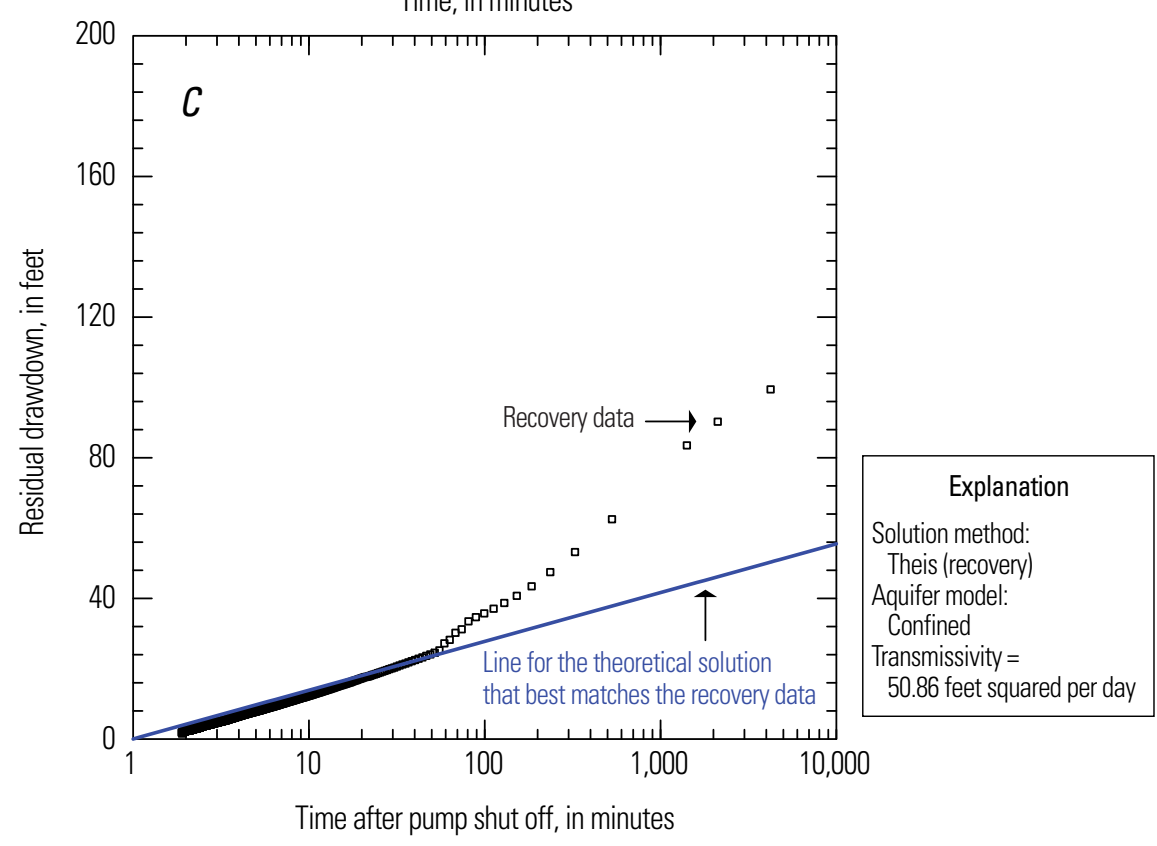


test was approximately $50 \mathrm{ft}^{2} /$ day (fig. $5 A-C$; table 1 ). The values of transmissivity and specific capacity for SMW-1 are at the low end of the range for the $\mathrm{N}$ aquifer when compared with data for other wells in the region (table 1). These lower values are to be expected given the location of SMW-1 at the western edge of the $\mathrm{N}$ aquifer where the saturated thickness of the formation is thinning and there is little fracturing in the formation to improve permeability (Cooley and others, 1969; Levings and Farrar, 1977).

Information on the specific capacity of a well is useful because it can be used to estimate the potential well yield. Specific capacity of a well is a function of the aquifer transmissivity, the design of the well, and how the well is tested. Higher aquifer transmissivity generally results in higher specific capacity values for a well. Specific capacities in unconfined aquifers generally are lower over time owing to a dewatering of the aquifer and decrease in saturated thickness. In general, given the same aquifer characteristics, wells with a larger radius will have greater specific capacity than wells with a smaller radius because there is more screened area for water to flow into the well. Wells with a smaller radius may also underrepresent the specific capacity owing to transmission losses between the well and the aquifer. The duration of the aquifer test also affects the estimation of specific capacity of the well owing to decreased effects of the well as drawdown conditions in the well near equilibrium with the aquifer. Pumping at a high rate will also result in lower than expected specific capacity owing to rapid dewatering of the well. Based on the step-drawdown test data, the specific capacity of the well is about 0.20 gallons per minute per foot $[(\mathrm{gal} / \mathrm{min}) / \mathrm{ft}]$ (table 1). The specific capacity of the well estimated from the constant-rate test was slightly less at $0.16(\mathrm{gal} / \mathrm{min}) / \mathrm{ft}$, owing to the greater drawdown over a longer pumping period. From these data and considering the well design, a reasonable pumping rate for this well would be about $15 \mathrm{gal} / \mathrm{min}$. This would result in a drawdown at the well of about $75 \mathrm{ft}$, or a little less than half of the available saturated thickness of the aquifer at the well. Well designs with larger diameters more consistent with public-supply wells in this area may result in slightly greater well yields. Sustainable well yields in this area, however, are limited by the relatively low transmissivity of the aquifer.

\section{Water Quality}

Water temperature, specific conductance, $\mathrm{pH}$, and dissolved-oxygen concentration were monitored hourly during the step test and constant-rate test. These parameters fluctuated very slightly during the tests (fig. $6 A-D$ ). The specific conductance stabilized at around 312-314 microsiemens per centimeter $(\mu \mathrm{S} / \mathrm{cm})$. This value is consistent with the value of $310 \mu \mathrm{S} / \mathrm{cm}$ measured from the $\mathrm{N}$ aquifer by Tetra Tech EM Inc. (2004) during zonal testing of the borehole. Tetra Tech EM Inc. also determined that the Kayenta Formation in this borehole has a specific conductance of $640 \mu \mathrm{S} / \mathrm{cm}$. This
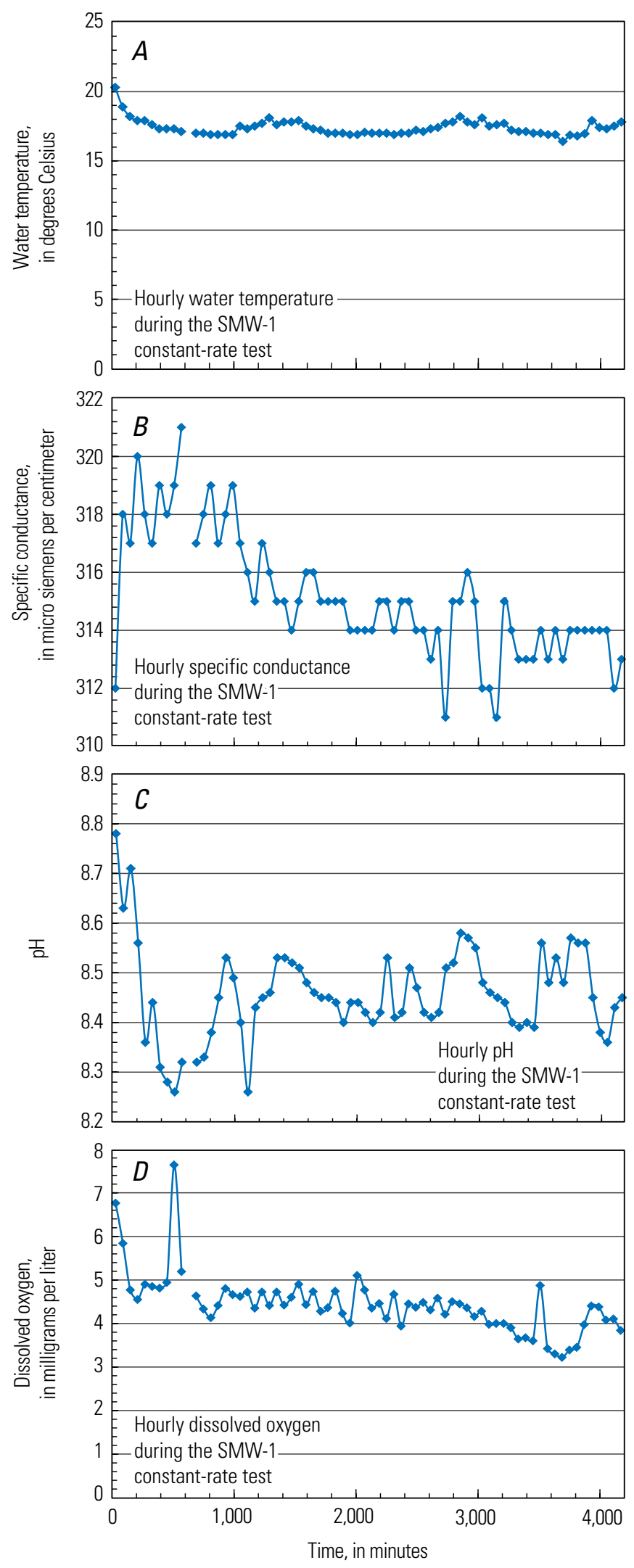

Figure 6. Graphs showing hourly water temperature, specific conductance, $\mathrm{pH}$, and dissolved oxygen during the constant-rate test at SMW-1 south of Moenkopi, Arizona; $A$. temperature, $B$. specific conductance, C. $\mathrm{pH}, D$. dissolved oxygen. 
suggests that the casing and construction of well SMW-1 may have effectively isolated water in the Navajo Sandstone from the poorer quality water in the underlying Kayenta Formation; however, a longer term preproduction test would help the Hopi determine if the lower Navajo Sandstone specific conductance would remain stable with time. The $\mathrm{pH}$ of water from the well ranged from 8.2 to 8.6 after stagnant water was evacuated from the well. After stagnant water was evacuated from the well, the dissolved oxygen decreased steadily from about $5 \mathrm{mg} / \mathrm{L}$ to $3 \mathrm{mg} / \mathrm{L}$ at the end of the tests. Based on these observations, the water quality of this well appears be suitable for public supply. Tetra Tech EM Inc., however, observed dissolved iron from the well slightly in excess of the U.S. Environmental Protection Agency (USEPA) maximum contaminant level (MCL) of $0.3 \mathrm{mg} / \mathrm{L}$ $(0.33 \mathrm{mg} / \mathrm{L}$; Tetra Tech EM Inc., 2004). The USGS collected no other water samples from this well during the tests for additional water chemistry analysis.

\section{Summary}

The $\mathrm{N}$ aquifer is the most productive aquifer in northeastern Arizona and provides industry, businesses, agriculture, and people in the Moenkopi/Tuba City area with a dependable water supply. However, the public water supply for residents of Upper Moenkopi and Lower Moencopi Villages on the Hopi Indian Reservation near Tuba City has been in decline in recent years, prompting the Hopi Tribe to drill three test wells near the villages to explore the potential for additional groundwater resource development south of Moenkopi Wash. This report summarizes results of step-drawdown, constant-rate, and recovery tests conducted by the USGS on one of these wells, well SMW-1, located south of Moenkopi Wash and about 2.5 mi south of Lower Moencopi Village.

Well SMW-1, as completed, had a static water level of $99.15 \mathrm{ft}$ below land surface at the beginning of the aquifer test and a saturated thickness of about $200 \mathrm{ft}$. Transmissivity of the $\mathrm{N}$ aquifer in the vicinity of the well is estimated to be about $50 \mathrm{ft}^{2} / \mathrm{d}$ on the basis of evaluation of data from the constantrate and recovery tests. The specific capacity of the well is about $0.16-0.20(\mathrm{gal} / \mathrm{min}) / \mathrm{ft}$. This suggests that a reasonable pumping rate for the well would be about $15 \mathrm{gal} / \mathrm{min}$ with about $75 \mathrm{ft}$ of drawdown (or a little less than half of the available saturated thickness of the aquifer at the well). Waterquality field parameters did not change significantly during the tests indicating that the well, as completed and tested, may limit movement of poorer quality water from the underlying Kayenta Formation upward into the well.

\section{References Cited}

Arizona Department of Water Resources, 2008, Preliminary Hydrographic Survey Report for the Hopi Indian Reservation: judicial proceedings entitled In re the General Adjudication of All Rights to Use Water in the Little Colorado River System and Source, No. 6417, 178 p. (Also available at http://www.azwater.gov/azdwr/SurfaceWater/ Adjudications/documents/03_Chapters.pdf.)

Cooley, M.E., Harshbarger, J.W., Akers, J.P., and Hardt, W.F., 1969, Regional hydrogeology of the Navajo and Hopi Indian Reservations, Arizona, New Mexico, and Utah, with a section on Vegetation, by O.N. Hicks: U.S. Geological Survey Professional Paper 521-A, 61 p., 9 plates.

Cooper, H.H., Jr., and Jacob, C.E., 1946, A generalized graphical method for evaluating formation constants and summarizing well field history: American Geophysical Union Transactions, v. 27, p. 526-534.

Driscoll, F.G., 1986, Groundwater and wells, second edition: Johnson Filtration Systems Inc., St Paul, Minn., 1,089 p.

Duffield, G.M., 2007. AQTESOLV for Windows Version 4.5 Professional, HydroSOLVE, Inc.

Eychaner, J.H., 1983, Geohydrology and effects of water use in the Black Mesa area, Navajo and Hopi Indian Reservations, Arizona: U.S. Geological Survey Water-Supply Paper 2201, 26 p.

Farrar, C.D., 1980, Maps showing groundwater conditions in the Hopi Area, Coconino and Navajo Counties, Arizona-1977: U.S. Geological Survey Open-File Report 80-3, scale 1:250,000, 4 sheets.

Hoffmann, J.P., Bills, D.J., Phillips, J.V., and Halford, K.J., 2006, Geologic, hydrologic, and chemical data from the C aquifer near Leupp, Arizona: U.S. Geological Survey Scientific Investigations Report 2005-5280, 42 p.

Hopi Tribe, 2003, Proposal for water resources evaluation south of Moenkopi Wash, northern Arizona: Submitted to the U.S. Bureau of Reclamation, Lower Colorado River Regional, Office of Native American Affairs, prepared by the Hopi Water Resources Department.

Kelly, V.C., 1958. Tectonics of the Black Mesa Basin Region of Arizona: Prepared in cooperation with the Arizona Geological Society for the Ninth Field Conference of the New Mexico Geological Society, edited by Roger Y. Anderson and John W. Harshbarger, p 137-144. 
Kruseman, G.P., and de Ridder, N.A., 1994. Analysis and evaluation of aquifer test data ( $2 \mathrm{~d}$ ed.): Publication 47, International Institute for Land Reclamation and Improvement, Wageningen, The Netherlands, $370 \mathrm{p}$. (Also available at http://www.alterra.wur.nl/UK/publications/ILRIpublications/Downloadable/.)

Levings, G.W., and Farrar, C.D., 1977, Map showing groundwater conditions in the southern part of the Black Mesa area, Navajo, Apache, and Coconino Counties, Arizona-1976: U.S. Geological Survey Water-Resources Investigations Report 77-41, scale 1:250,000, 3 plates.

Lopes, T.J., and Hoffmann, J.P., 1997, Geochemical analyses of groundwater ages, recharge rates, and hydraulic conductivity of the $\mathrm{N}$ aquifer, Black Mesa area, Arizona: U.S. Geological Survey Water-Resources Investigations Report 96-4190, $42 \mathrm{p}$.

Macy, Jamie P., 2010, Groundwater, surface-water, and water-chemistry data, Black Mesa area, northeastern Arizona-2008-2009: U.S. Geological Survey Open-File Report 2010-1148, 43 p.

Papadopulos, I.S., and Cooper, H.H., 1967, Drawdown in a well of large diameter: Water Resources Research, v. 3, no. 1, p. 241-244.

Tetra Tech EM Inc., 2004, Water resource evaluation south of Moenkopi Wash, Moenkopi District of the Hopi Indian Reservation, Coconino County, Arizona: 13 p.

Theis, C.V., 1935, The relation between the lowering of the piezometric surface and the rate and duration of discharge of a well using groundwater storage: American Geophysical Union Transactions, v. 16, p. 519-524.

U.S. Department of Health and Human Services, 2008, Project summary, Moencopi well study, Hopi Indian Reservation, Navajo and Coconino Counties, Arizona: Project Number PH-D78, $10 \mathrm{p}$. 

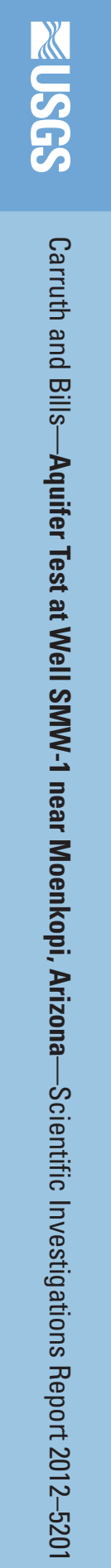